\title{
Chief Feature of Rocks of the Earth's Crust within Kimberlite Provinces - Moderation of their Petrochemical Indicators
}

Mitioukhine, S.I.

YaGEER\&D CNIGRI, ALROSA Co. Ltd. Chernyshevsky Sh. 7, Mirny, 678170, Sakha (Yakutia), Russia.

\section{Introduction}

It was repeatedly noted that kimberlites and associated with them magmatic rocks derivatives of mantle substrate were regularly located on territories of ancient platforms. The hypothesis is formulated that there is interrelation between the events in Precambrian (the stage of mantle evolution before the platform and the formation of primary Earth's crust) and magmatic processes in Phanerozoic. It is proved that the initial appearance and the conditions of rock formation of the Earth's crust within kimberlite provinces are peculiar and have no analogs on other sites of platforms, where there are no kimberlites and convergent to them rocks.

Actual data

Both xenoliths of rocks of the Earth's crust from kimberlite bodies of Yakutian kimberlite province and samples of core of deep boreholes, which have revealed crystalline basement of the platform, were investigated by methods of petrography, mineralogy and petrochemistry $(1,2)$. The analysis of actual data indicates that among xenoliths there prevail granulites, enderbites, charnockites, marbles, calcite rocks. Granulites are represented by garnet-ñlinopyroxene-plagioclase and bipyroxene-plagioclase crystalline shales, corresponding by petrochemical composition to tholeitic basalts. Enderbites and charnockites represent the rocks of a transitive stage from granulite metabasites to granites. Amphibolites correspond by petrochemical indications to varieties of basites.

Among the samples of core of deep boreholes two genetic types of rocks prevail. Granitoids (bimicaceous and biotite plagiogneisses, granite gneisses) and gneisses (bipyroxene and hypersthene) relate to the first type. Metabasites, in which the main rock-forming mineral is amphibole, relate to the second type.

Distribution of $\mathrm{MgO}$ and $\mathrm{SiO}_{2}$, according to the data of petrochemical investigations, is given in Fig. 1. Attracts attention low magnesian property of rocks ( $>10 \%$ in individual samples) at average level of silica content at $65-70 \%$. Histogram has clearly expressed bimodal appearance. It seems that xenoliths characterize lower parts of the Earth's crust. This is the so called "basalt" layer with increased mafic property $\left(\mathrm{SiO}_{2} 30-40 \%\right)$ at average magnesian property of $9-13 \%$. In its turn the core of boreholes makes it possible to characterize only upper levels of the crust within "granite" layer. In the rocks of the layer the content of $\mathrm{SiO}_{2}$ reaches $65-70 \%$ at magnesian property less than $5 \%$. The adduced data testify about the spreading of metarocks of moderate petrochemical specialization in the section of the crust of Yakutian kimberlite province. The rocks with indications "ultra" (ultrabasic, alkaline-basic, alkaline-sour) are not revealed in the section.

Geodynamic conditions of crust formation

Material characteristics of metarocks and structural interrelation of mineral masses make it possible to restore geodynamic conditions of formation of the Earth's crust within Yakutian kimberlite province. It was established by geochronological investigations that the formation of crust occurred 
in the course of two stages. In Archean there was the development of geosyncline with the formation of the section of volcanic (tholeitic basalts) and sedimentary (terrigenous and carbonate formations) rocks. On the boundary of 3.0 milliard years the primary crust suffered regional metamorphosis of granulite facies in the result of global compression of mineral masses. Later, in Late Archean-Early Proterozoic (1.8-2.0 milliard years) on the contacts of granulite blocks there occurred laying of zones of fluid permeability and diaphthoresis and creation of P-T conditions corresponding to amphibolite facies of metamorphosis.

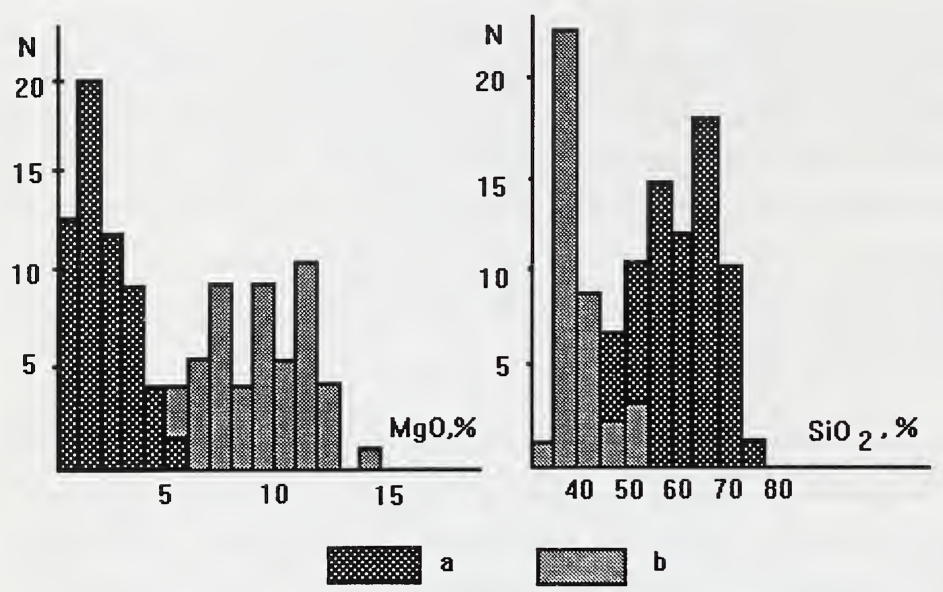

Рис. 1. Распределение содержании́ $\mathrm{MgO}$ и $\mathrm{SiO} 2$ в породах земнои́ коры: а - образцы из керна глубоких скважин, b - образцы ксенолитов коровых пород из кимберлитовых трубок.

Fig. 1. Distribution of content of $\mathrm{MgO}, \mathrm{SiO}_{2}$ in the rocks of the Earth's crust: a - xenoliths from kimberlites, b - samples of core of deep boreholes.

Collisional interrelation of the crust's blocks in zones of diaphthoresis may be equated with global thrust-faults. Directly in collisional zones there occurred magmatic phenomena: due to melting of Archean gneisses massifs of anorthosites (with the size to $15-20 \mathrm{~km}$ ) - monomineral plagioclase rocks, were formed.

A rather limited spectrum of magmatic rocks, which were formed both at the first and the second stage of the crust's evolution, attracts attention to itself: those are basalts - derivatives of mantle substrate at the initial stage of primary mantle differentiation, as well as the products of the crust's melting - basic and moderately sour rocks. One may suppose that the crust was forming in conditions of tangential compression and all geodynamic system is similar to the system of the closed type. As a consequence in the section of the crust no noticeable effect of endogenic mantle processes is revealed, which is expressed in the absence of magmatic rocks of ultrabasic, alkalinebasic and alkaline-sour specialization.

Petrological interpretation.

It is considered to have been proved that the centres of kimberlite magma and magmas of associated rocks are formed in the areas of ascending flows of fluids from lower mantle (3). Juvenile substance is involved in reactions, which is supported by indications of metasomatic transformations in nodules of mantle rocks. One can suppose that the intensity of chemical reactions depends not only on inertia of juvenile substance' components (rare-earth elements, noble gases, alkali, $\mathrm{N}, \mathrm{CO}_{2}, \mathrm{H}_{2} \mathrm{O}$, 
$\mathrm{Cl}, \mathrm{H}_{2} \mathrm{~S}, \mathrm{P}_{2} \mathrm{O}_{5}$ ), but on the degree of lithosphere's permeability. A supposition follows that in geodynamic systems of closed type, the pattern of which is the Earth's crust of kimberlite provinces, metasomatic transformations on individual sites in the upper mantle have anomaly character. This is of its kind process of "anti-depletion" or secondary benefication of the mantle. One can also suppose that favourable conditions for diamond-formation (in particular by model of redox-melting) are created in the closed geodynamic system.

\section{References}

Spetsius, Z.V., Serenko, V.P., 1990, Composition of continental upper mantle and lower strata of the crust under the Siberian Platform: M., Nauka.

Solovyeva, L.V., et al., 1994, Kimberlites and associated rocks. Substance of upper mantle under ancient platforms: Novosibirsk, Nauka.

Sobolev, V.S., Petrology of upper mantle and the origin of diamonds: Novosibirsk, Nauka. 